\title{
Onofre Lovero (1925-2012): Cuando un maestro emprende la gira
}

\section{Carlos Fos}

No es fácil despedir a un teatrista que ha realizado aportes fundamentales al campo artístico argentino. Mucho más complejo es hacerlo a un ser humano que sostuvo con su ética y la férrea convicción en sus principios cada proyecto que encaró hasta su último día de vida. Este vecino de Villa Crespo, nacido en 1925, descubrió una vocación que sería imposible separar del resto de las actividades que desarrolló: el teatro. Teatro y Lovero fueron las dos caras de una misma moneda desde 1942, cuando armó un grupo con sus compañeros de quinto año del Nacional Buenos Aires y representaron En familia de Florencio Sánchez. Lovero la dirigió e interpretó el personaje de Jorge. Alquilaron el Teatro Lasalle, la utilería y todo el personal de la sala para representarla. Luego siguió el paso por la Facultad de Arquitectura, truncado por su real amor: la actuación. Ingresó a dos grupos de teatro independiente, en los que inició su formación: El Teatro Experimental Argentina y el Tinglado Libre Teatro, donde intervino en la primera puesta de El gigante Amapolas de Alberdi, un siglo después de escrita. Tuvo participación en el estreno de El oso de Chéjov, la primera incursión de nuestra escena en la poética de este maestro ruso. Lo hizo, integrando Nuevo Teatro, del que se fue para fundar su propio proyecto: El Teatro de los Independientes. Esta quijotada, donde se acondicionó un precario local ubicado en la calle San Martín 766, se convirtió en una de las expresiones de mayor madurez del teatro independiente, junto a Nuevo Teatro, el IAM, La Máscara y Fray Mocho. Gestor intuitivo, lo encontramos en el seno de la FATI, núcleo de reunión de los teatros independientes, con la capacidad de trabajo que lo definía. Repasar su trayectoria en la escena porteña (también pobló los teatros oficiales), en el cine y en la televisión no tiene sentido, pues Lovero supera la mera crónica o los premios recibidos. Fue generador de la Unión Cooperadora de Teatros Independientes 
y, junto a otros compañeros, creó el Teatro Popular de la Ciudad en 1972. Tuvo una existencia marcada por el compromiso con el semejante y por ello una destacada acción gremial que lo llevó a ser co-fundador de la Asociación de Directores de Teatro y vicepresidente y secretario general del Centro Argentino del Instituto Internacional del Teatro, adscripto a la UNESCO. Referente en Teatro Abierto, ese espacio de resistencia desde el teatro a la última dictadura militar, intervino en el Movimiento de Apoyo al Teatro para conseguir una legislación que amparara la actividad teatral. Fue presidente del Bloque Latinoamericano de Artistas y vicepresidente de la Federación Internacional de Actores y del Centro Latinoamericano de Creación e Investigación Teatral (CELCIT), con sede en Venezuela.

Sus últimos años lo encontraron al frente de Proteatro, siendo un referente de consulta para los integrantes de su directorio. Un gran orador, un anecdotario viviente, un hombre que sorteó una de las dificultades mayores: ser coherente en palabras y hechos.

Centro de Documentación Teatral del Complejo Teatral de Buenos Aires (CTBA)

Asociación Argentina de Investigación y Crítica Teatral (AINCRIT) 